\title{
Online Customer Reviews on Restaurants and Expert Opinions: An Integrated Approach
}

\author{
Asst. Prof. Dr. Ramazan GÖRAL \\ Selcuk University/Konya \\ trgoral@selcuk.edu.tr
}

\author{
Res. Assist. Simge TOKAY \\ Selcuk University/Konya \\ simge_tokay@hotmail.com
}

\begin{abstract}
In recent years, online customer reviews have been widespread and it has been taken into account in the point of the decision by the people. Resources which create a virtual environment interaction are developing with the user reviews and ratings and it is increasingly gaining importance for both customers and tourism businesses. Customers, who are evaluating food and beverage consumption as an experience and looking at truelife experiences when deciding which experience to lives, are more increasingly using online resources serving sector. These platforms provide the customers the opportunity of dialoguing among them and provide information while they provide feedback for the improvements for the service providers they need to do. Because of these properties, researchers argue online customer reviews and they express that services restaurant could offer and the quality of them could be compared better by using customer feedback. However, customer review system has been criticized. The point critics pointed is the difficulty of verification reviews and deficiencies in impartiality point. An integrated approach is proposed in this study. Online customer judgments assessing the food and beverage business and expert opinions underlie the integrated approach. For this purpose, the data obtained from TripAdvisor website and expert reviews will be integrated with Analytical Hierarch Process (AHP) method. In the study, restaurants which take place in Turkey's biggest tourist areas in four provinces and locating in the top 10 according to customer rewievs on TripAdvisor website are evaluated. Then, arithmetical average of the aggregated customer ratings relating to these restaurants and the integration of assessment of experts providing training in food and beverage area are ensured. Consequently, these four provinces' rank is determined by an integrated approach in terms of restaurants.
\end{abstract}

Keywords: e-WOM, Analitik Hiyerarşi Proses.

\section{Introduction}

In many studies it was found that potential consumers were influenced by comments of other consumers in the decisionmaking phrase and they see each of the this review as a reference source (Bilim et al., 2013; p.388). For example, according to a survey done by TripAdvisor in 2012 and took place with more than 1700 participants, $64 \%$ of the respondents act in their vacation plans according to the review of the website (Civelek, 2013; p.273). According to the reports based on etransactions, the hundreds of millions of potential tourism customers each year see comment pages as their guide. Studies on consumer e-rewievs emphasize that consumer rewievs are an important factor on the hotel selection and decisionmaking (Bilim et al., 2013; p.392-393). Before booking a hotel, customers are visiting 14 different travel sites on condition that looking at least 3 average per site visitors' opinions and they are conducting 9 research related to their travel in search engines (UNWTO, 2014, p.10).

The abstract quality of the food and beverage services, consequently, the high risk perception of the consumer and inadequency of the points providing information to be contacted personally or to reduce the risk perception direct consumers to reviews as e-information sources. Potential consumer perceive online reweievs as an expert opinion. On behalf of making inference and evaluation, online reviews are an important reference. In this regard online rewievs as a source of information look more convincing than the information in advertising and other marketing tools by consumers. The sites that publish customer reviews direct consumers as a source of information for this purpose. For example, Tripadvisor, which is an international platform germane to tourism and travel, independently gives consumers information they can use in the 
selection of restaurants, it also offers orderings on the basis of businesses in the sector. Being in the top positions in the comment pages concerning international arena like these and similar, as well as being a source of prestige, direct consumer preferences at the same time.

However one of the problems with the customer reviews is their credibility. Studies show that businesses provide incentives for being written imaginary (fictional) positive comments about them and being written negative comments for opponent businesses (UNWTO, 2014, p.14).

The purpose of this study is to evaluate online customer judgments evaluating food and beverage businesses and expert opinions in a combination of integrated approach. For that purpose, restaurants which take place in Turkey's biggest tourist areas in four provinces and locating in the top 10 according to customer rewievs on TripAdvisor website are evaluated. At the same time, with the survey, expert opinions related to criterias used in evaluating the service and quality of the restaurant in TripAdvisor website were received. Afterwards, the data obtained from TripAdvisor website and expert reviews were integrated with Analytical Hierarch Process (AHP) method.

The study consists of five chapters, including the introduction. After the introductory section, eWOM (electronic consumer reviews) and its relationship with the food and beverage business is assessed under the relevant literature in the second part. In the third part, AHP method by which the data were evaluated and application steps were dealt. In the fourth section, method, analysis and findings are included. In the last section, the results are discussed.

\section{2. eWOM (Electronic Consumer Reviews) and Food and Beverage Businesses}

In the past, consumers would refer to the views of other people around them in order to find out his thoughts on a certain brand, product, or business and this case would be known as Word of Mouth in marketing literature. In paralel with the development of computer and Internet technology, personal comments and opinions are being shared in a virtual environment (Pollach, 2006; p.1). This communication which means consumers do not recognize each other over the Internet, they share their comments via consumers is called eWOM (electronic publicity) (Bilim et al., 2013; p.390). In this context, eWOM is; " significant remarks, or product viewed, by prospective, current, or former consumers". eWOM involves comments about product performance, service quality, and trustworthiness passed on from one person to another using an electronic medium (Arroyo and Pandey, 2010; p. 1230).

Today, thanks to the idea of web-based sharing platforms' popularity and proliferation, it plays an important role in online product evaluations and purchase decisions of consumers. These online platforms allows individuals to share their experiences with other people. These communities which are constantly increasing not only provide customers to spread their ideas but also assist the businesses to give their marketing messages by electronic word of mouth communication (eWOM). Online customer reviews for the food and beverage business are very effective. Because there is no possibility of testing of the product before being consumed in the restaurant. An information obtained from an experienced source with an eWOM will also help the customer's decision making (Zhang et al, 2010).

The reasons such as economic developments in our day, globalization, the impact of media on life style, workload, the active women in working life, a request of spending enjoyable time albeit two-hours at the end of a tiring and stressful day, fashion, pleasure and desire to socialize, the development of travel cases, the request of getting food and drinks availably which can not be obtained or can not be produced in the home environment (Sarışık and Hatipoğlu, 2009; p.186) have changed people's eating habits and continue to change. Individuals who meet these needs in a home environment with household before, also meet the needs of eating and drinking outside with the influence of the above reasons today. When consumers consider in terms of the cost they endured and the value they gained, value presentations that consumers expect from the food and beverage business vary from the value presentations which they expected from other product groups. This is because consumers who save time and money to buy the food and beverage of business services want to live the experience without any surprise in negative sense. To avoid any negative experiences, they collect information from various information resources about products and / or services. While this information resources were limited with the information obtained from traditional media and social environment (the reference group) in the past, today sufficient information is presented to consumers in the online environment (Özaslan and Uygur, 2014; p.70).

According to a study conducted by Jeong Jang (2011), restaurants' food quality provide positive eWOM between customers. Service employees are also among the factors that create a positive eWOM. A good atmosphere in the restaurant is another factor contributing to the positive eWOM. The reasonable prices in the restaurants are not contributing to customers on eWOM. 
Zhang et al (2010) analyzed customer reviews about food, atmosphere and service quality of restaurants in their research. They have tried to identify the impact of eWOM on the popularity of restaurants in virtual environment. As a result, the density of online customer reviews is directly associated with the virtual popularity of the restaurant (Sarışık and Özbay, 2012; p.14).

Boulding et al. (1993) draw attention that service quality in restaurants has positive effect on customer behaviors such as loyalty and positive eWOM.

These studies clearly demonstrate the importance of online reviews in the food and beverage sector. As the importance of online reviews increases in terms of customer, the interest, assessments and strategies of food and beverage business are evolving in this direction. Food and beverage businesses, except for the comments for them, can be created important source of information in determination of market developments and the development of competitive strategy by taking into account the company reviews of other competitors in the industry.

\section{Analytic Hierarchy Process (AHP) Method}

AHP has been developed for the solution of complex multi-criteria decision-making problems by Saaty in the 1970s. AHP is multi-criteria decision-making technique which can take into account both objective and subjective evaluation criteria and is widely used (Özen ve Orçanlı, 2013). It is a technique which needs the views of decision-makers in determination of the relative degree of importance on all criteria. Decision-makers compare criteria and sub-criteria using Saaty's 1-9 scale (Table 1). By evaluating all criteria, priority of decision alternatives is obtained (Önder and Önder, 2014; p.21-22).

\section{Table 1: Saaty AHP Paired Comparison Scale}

\begin{tabular}{|l|l|}
\hline Significance values & Value Description \\
\hline 1 & Status of both factors' equal importance \\
\hline 3 & Status of Factor 1 is more important than Factor 2 \\
\hline 5 & Status of Factor 1 is far more important than Factor 2 \\
\hline 7 & Status of Factor 1 is highly significant compared to Factor 2 \\
\hline 9 & Status of Factor 1 is very highly significant compared to Factor 2 \\
\hline $2,4,6,8$ & Intermediate values of degrees in the above description in the choice between two factors \\
\hline
\end{tabular}

Reference: (Saaty,2008;86)

In problem solving with AHP, object (problem) is determined first, then AHP solution steps are implemented starting from the object. Solution phase with AHP operates in the following way (Timor 2011;18, Önder and Önder 2014;23-24);

Step 1: Decision problem is defined and purpose is determined.

Step 2: Necessary decision criteria are set to achieve the objective.

Step 3: Possible decision alternatives are determined.

Step 4: The hierarchical structure of decision problems are created. 


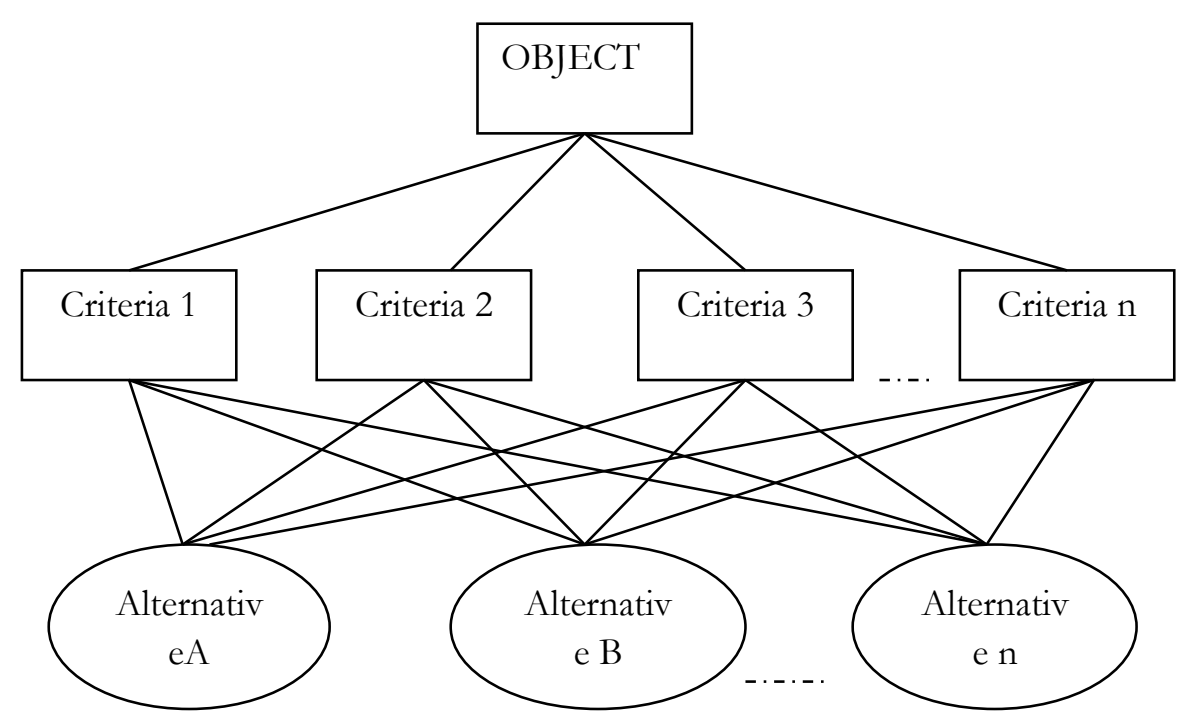

Figure 1: AHP's Hierarchical Structure

Step 5: Paired comparison of the criteria for each level of the hierarchy and the degree of importance of criteria is determined by taking advantage of eigenvectors.

At this stage, inter-criteria comparison matrix is a $n x n$ dimensional square matrix. Matrix components on the diagonal of this matrix takes the value 1 . Comparison matrix is shown below:

$$
A=\left[\begin{array}{cccc}
a_{11} & a_{12} & \ldots & a_{1 n} \\
a_{21} & a_{22} & \ldots & a_{2 n} \\
\cdot & & & \cdot \\
\cdot & & & \cdot \\
\cdot & & & \cdot \\
a_{n 1} & a_{n 2} & \ldots & a_{n n}
\end{array}\right]
$$

Comparison of criteria is done one-to-one and mutual according to importance values that they have relative to each other. In comparison of criteria mutually AHP comparison scale in Table 1 is used. In order to determine the weight of these criteria in integrate, in other words their percent importance distributions, it is utilized from column vectors forming the comparisons matrix and $B$ column vector with $\mathbf{n}$ number and $\mathbf{n}$ component is generated. This vector is shown below: 
$B_{i}=\left[\begin{array}{c}b_{11} \\ b_{21} \\ \cdot \\ \cdot \\ \cdot \\ b_{n 1}\end{array}\right]$

In the calculation of $\mathrm{B}$ column vector, it is utilized from $b_{i j}=\frac{a_{i j}}{\sum_{i=1}^{n} a_{i j}} \quad$ formula.

When the steps described above is repeated for the other evaluation criteria, $B$ column vector will be obtained about the number of criteria. When $\mathrm{n}$ number $\mathrm{B}$ column vector is combined in a matrix format, $\mathrm{C}$ matrix will be formed as shown below:

$$
C=\left[\begin{array}{cccc}
c_{11} & c_{12} & \ldots & c_{1 n} \\
c_{21} & c_{22} & \ldots & c_{2 n} \\
\cdot & & & \cdot \\
\cdot & & & \cdot \\
\cdot & & & \cdot \\
c_{n 1} & c_{n 2} & \ldots & c_{n n}
\end{array}\right]
$$

Benefitting from the $\mathrm{C}$ matrix, percent importance distributions which indicate importance values of the criteria relative to each other can be obtained. For this, as shown in the Formula (1), arithmetic average of the line components composing $\mathrm{C}$ matrix is taken and W column vector, called Priority Vector, is obtained. W vector is shown below:

$$
w_{i}=\frac{\sum_{j=1}^{n} c_{i j}}{n}
$$

$$
W=\left[\begin{array}{c}
w_{1} \\
w_{2} \\
\cdot \\
\cdot \\
\cdot \\
w_{n}
\end{array}\right]
$$

Step 6: The consistency of the comparison matrix obtained in the previous step is determined. 
AHP , with Consistency Rate (CR) obtained, provides the opportunity to test the priority vector which was obtained and hence the consistency of one-to-one comparisons which were made between the criterias. AHP attributes the essence of $\mathrm{CR}$ calculation to the number of criteria and the comparison of a factor $(\lambda)$ which is called Basic Value. For calculating $\lambda$, first, $\mathrm{D}$ column vector is obtained from matrix multiplication of $\mathrm{A}$ comparison matrix with $\mathrm{W}$ priority vector.

$$
D=\left[\begin{array}{cccc}
a_{11} & a_{12} & \ldots & a_{1 n} \\
a_{21} & a_{22} & \ldots & a_{2 n} \\
\cdot & & & \cdot \\
\cdot & & & \cdot \\
\cdot & & & \cdot \\
a_{n 1} & a_{n 2} & \ldots & a_{n n}
\end{array}\right] x\left[\begin{array}{c}
w_{1} \\
w_{2} \\
\cdot \\
\cdot \\
\cdot \\
w_{n}
\end{array}\right]
$$

Dividing the corresponding elements of $D$ column vector that was found and $W$ column vector, the value for each evaluation criterion $(E)$ is obtained. The arithmetic average of these values (2) gives the basic value $(\lambda)$ related to the comparison. After calculating $(\lambda)$, Consistency Index (Cl) can be calculated by utilizing the formula (3). At the final stage $\mathrm{CR}$ is obtained by dividing $\mathrm{Cl}$ into standard correction value (4) called Random Index (RI) shown at Table 2.

$$
\lambda=\frac{\sum_{i=1}^{n} E_{i}}{n}
$$

$$
C I=\frac{\lambda-n}{n-1}
$$

$$
C R=\frac{C I}{R I}
$$

If the calculated value of $\mathrm{CR}$ is smaller than 0.10 , this indicates that decision maker made consistent comparison. If $\mathrm{CR}$ value is greater than 0.10 , this shows there is a calculation error in AHP or inconsistency in decision making's comparisons.

\section{Table 2: Random Index (RI) Values}

\begin{tabular}{|l|l|l|l|l|l|l|l|l|l|l|l|l|l|l|l|}
\hline $\mathrm{N}$ & 1 & 2 & 3 & 4 & 5 & 6 & 7 & 8 & 9 & 10 & 11 & 12 & 13 & 14 & 15 \\
\hline $\mathrm{RI}$ & 0 & 0 & 0,58 & 0,90 & 1,12 & 1,24 & 1,32 & 1,41 & 1,45 & 1,49 & 1,51 & 1,48 & 1,56 & 1,57 & 1,59 \\
\hline
\end{tabular}

Reference: (Saaty and Özdemir,2003; 241)

Step 7: Severity of the alternatives and criteria (weights) are determined. Alternative having the highest weight is the best alternative, criteria having the highest weight is the best criteria.

\section{Method of the Research}

One of the fundamental principles of AHP is the decomposition. Decomposition states hierarchical configuration of the problem (Saaty, 1986;p.841). The objective, criteria and alternatives are three basic levels of hierarchical configuration. The object of Hierarchical Configuration is identified as the sequencing of the four provinces having most tourist areas in terms of food and beverage businesses with an integrated approach. As the criteria, four criteria used in scoring on TripAdvisor website are used exactly in the study. In importance weighting of these criteria, the views of lecturers, who work at food and beverage section at Beyşehir Tourism Faculty, have been consulted. The views related to criteria of five 
lecturers were taken through a questionnaire prepared according to Saaty 1-9 scale. Then, by converting the personal jurisdictions of each decision makers to group joint decision by the geometric mean, weigths were calculated in Super Decision program. Customer ratings on TripAdvisor website are included into the calculation as the values taken by the alternative.

The following sequence was followed in the analysis of the study:

1. Defining the decision problem, objectives, criteria and the creation of hierarchical model by identifiying the alternatives clearly,

2. Calculation of the average criteria of the Top 10 restaurants according to customer review on TripAdvisor site in the provinces which are determined alternatively,

3. Calculation of the degree of importance (weight) of the criteria by making the paired comparison of the criteria for each level of the hierarchy,

4. Determination of the ranking of the alternatives.

The portion for the analysis of the study is detailed below in accordance with this order.

\subsection{Defining the Problem Resolution with AHP Method, Objective, Criteria and Creating the Hierarchical Model by Specifying of Alternatives}

Decision problems and objectives of the application are "the comparison of the first four provinces having most tourist areas in Turkey in terms of food and beverage services" in the scope of expert assessments and the scores given by the customer. As criteria for analysis, restaurant customer reviews criteria are selected on TripAdvisor site which is an international platform related to tourism and travel. In this context, there are 4 criteria in the decision problem including service, food, atmosphere and value.

In the study, a full round is accepted as awful= 1 point, two full round as bad= 2 points, three full round as mean= 3 points, four full rounds as alpha plus= 4 points, five full rounds as perfect $=5$ points which take place under the title of TripAdvisor site score summary. Rounds, which are half full, are evaluated as $1 / 2$.

As the alternatives, Antalya, İstanbul, Muğla, İzmir provinces are determined as the most tourist areas in Turkey (TUROFED, 2014). Therefore, there are four alternatives in problem resolution. In light of this information, Hierarchical Model of problem Decision was created. Model for the problem is combined with the arrows from top to bottom (Figure 2).

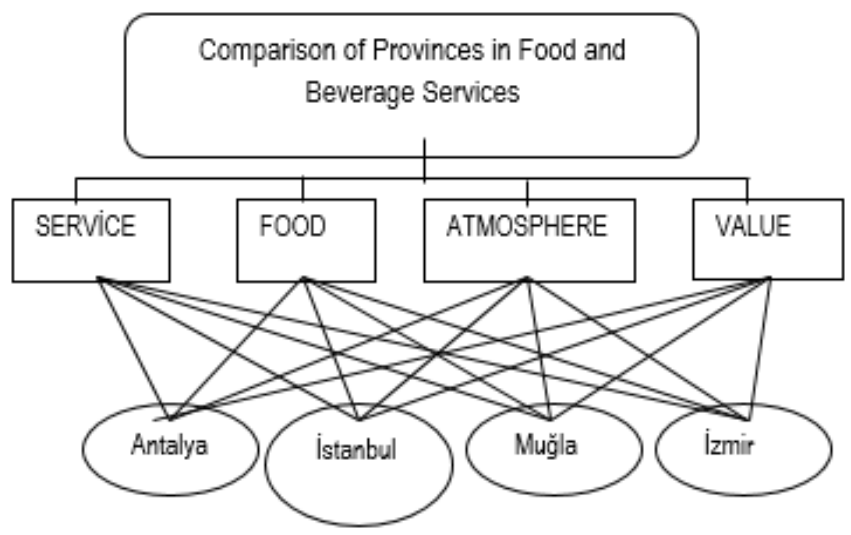

Figure 2: Decision Problem Hierarchical Model 


\subsection{Calculation of Criteria Average in Alternative Cities}

According to customer ratings on TripAdvisor website in four provinces having most tourist areas in Turkey, the values in Table 3 were obtained by calculating the arithmetic average of the scores of the restaurants which take place in top ten, according to Service, Food, Atmosphere and Value criteria.

Table 3: Average of Customer Satisfaction Criteria of Four Provinces

\begin{tabular}{|l|l|l|l|l|}
\hline & ISTANBUL & ANTALYA & IZMiR & MUĞLA \\
\hline Service & 4,87 & 4,31 & 4,61 & 5,00 \\
\hline Food & 4,63 & 4,38 & 4,77 & 4,92 \\
\hline Atmosphere & 4,42 & 4,31 & 4,29 & 4,69 \\
\hline Value & 4,40 & 4,36 & 4,69 & 4,77 \\
\hline General Average & $\mathbf{4 , 5 8}$ & $\mathbf{4 , 3 4}$ & $\mathbf{4 , 5 9}$ & $\mathbf{4 , 8 5}$ \\
\hline
\end{tabular}

1.3. Determination of Degree of Importance (the weight) of Criteria by Paired Comparison of Criteria for Each Level of the Hierarchy with AHP Method

After criteria averages calculated in alternative provinces, paired comparisons of the criteria (service, food, atmosphere, value) were started. The data used in the paired comparison were obtained by the questionnaire which was prepared by using 1-9 scale of Saaty (Table 1). The questionnaire was filled to 5 lecturers at Tourism Faculty in Beyşehir. Then, the geometric mean of the personal judgment obtained from the survey was calculated (Table 4). Thus, expert review group decision was obtained before paired comparison.

Table 4: Expert Review Group Decision on Paired Comparison

\begin{tabular}{|l|l|l|l|l|l|l|l|l|}
\hline Criteria & K.V.1 & K.V.2 & K.V.3 & K.V.4 & K.V.5 & Geo.Mean. & Common Review & Criteria \\
\hline Atmosphere & $1 / 5$ & $1 / 6$ & $1 / 5$ & $1 / 3$ & $1 / 5$ & 0,21 & $1 / 5$ & Value \\
\hline Atmosphere & $1 / 3$ & $1 / 8$ & $1 / 7$ & $1 / 6$ & $1 / 8$ & 0,17 & $1 / 6$ & Service \\
\hline Atmosphere & $1 / 3$ & $1 / 9$ & $1 / 9$ & 5 & $1 / 5$ & 0,33 & $1 / 3$ & Food \\
\hline Value & 3 & $1 / 8$ & 5 & $1 / 5$ & $1 / 6$ & 0,57 & $1 / 2$ & Service \\
\hline Value & 3 & $1 / 7$ & 2 & 1 & $1 / 7$ & 0,70 & $1 / 2$ & Food \\
\hline Service & $1 / 2$ & $1 / 9$ & $1 / 9$ & 4 & 5 & 0,66 & $1 / 2$ & Food \\
\hline
\end{tabular}

AHP can be applied in individual and group decision. If the decision is taken by participation of not only one person but a group, the name of AHP with the group deciding is given to this case (Giriner and Çevdar, pp.104-105). One of the commonly used methods when group decision given in AHP is combination of individual judgment which is located in the pairwise comparison matrix. In cases where decision-makers have equal importance in combining of the judgment of a group, geometric mean is the most appropriate method Forman and Peniwati, 1998; p.169, Asma and Bahurmoz, 2006; p.10, Timor, 2011; p.38, Ömürbek and Tunca, 2013; pp. 56-57, Önder and Önder, 2014; pp.35-37, Çelik, 2007; p.74).

If the calculated geometric mean value was between 1-9, compare results were entered into the left side of the questionnaire Super Decision program without making any changes. If the geometric mean was a decimal number, nearest integer value was taken. If the geometric mean value which was calculated for decision makers is in the range of $0-1$, "1" value is divided into this value (like $1 / 0,60$ ). If the value is decimal number on account of dividing, it is calculated as " $1 /$ the obtained value" by taking into account the closer integer value. In Table 4, fractional numbers which take place in common review 
column field were determined in this way and Super Decision program was included in the calculation in the manner of locating on the right side of the questionnaire form (Ömürbek and Tunca 2013; pp.58-59). After data input, matrix concerning the criteria was created.

Inconsistencies in comparison may result in inconsistence of priority values of the ordering preferences of alternatives. If the inconsistency rate is "0", it shows that decision-maker is completely consistent in his jurisdiction. If this rate is $10 \%$ or lower, it is generally acceptable (Hafeez et al., 2002; p39, Forman and Selly, 2001; p.49). As the discrepancy value $(0,09914$ $<0,10)$ of pairwise comparisons of individual judgment of decision makers is within acceptable limits which was calculated by taking the geometric mean in the study, the value related to the priority vector was adopted as interpreted. In this context, weight values of criteria as a result of comparisons are as follows; Service $(32 \%)$, Food $(39 \%)$, Atmosphere $(7 \%)$, Value $(22 \%)$. based on the results, the most important criteria in the selection of restaurant is food for decision-makers, the most trivial criteria is atmosphere.

\subsection{Determining of Precedence of the Alternatives}

As a result, according to evaluation scores given by the customer in the restaurants which were taken into consideration in four provinces and judgment of experts in weighting of the criteria orderings are as shown in Table 5 .

Table 5: Comparison of the Restaurants of Four Provinces in terms of Customer Satisfaction

\begin{tabular}{|l|l|l|l|}
\hline & ORDERING IN TERMS OF CUSTOMER REVIEWS & \multicolumn{2}{|l|}{ INTEGRATED ORDERING } \\
\hline MUĞLA & 4,83 & MUĞLA & 0,264 \\
\hline IZMIR & 4,59 & İMIR & 0,252 \\
\hline ISTANBUL & 4,58 & ISTANBUL & 0,250 \\
\hline ANTALYA & 4,34 & ANTALYA & 0,234 \\
\hline
\end{tabular}

As can be seen from Table-5, general ordering in our study which assesses of judgment of experts with the ordering in terms of the customer rewievs on the restaurants which take place in four provinces having most tourist areas in Turkey hasn't changed.

\section{Conclusion}

In recent years, with technology providing opportunity of sharing unlimited information and comments in the virtual environment and increase in people's willingness to get information have attracted attention to this environment. Word of mouth communication which is an important marketing tool has begun to give place to word of mouth communication in virtual environment, rewievs of customers and ratings. In tourism industry, the importance of experience consumption rather than product has triggered consumers' to share positive or negative experiences, which they lived, with potential consumers in virtual environments. Research results show that a large number of potential tourists decide to buy or not to buy by evaluating the views of those who has experience in the virtual environment.

As well as being many internet environment where restaurant customers share their experience, TripAdvisor website, which is an international platform where restaurant customers share their experience, is recognized as an important source in academic works. In this context, in four provinces having most tourist areas in Turkey and restaurants which take place in top 10 according to customer scoring in these provinces on TripAdvisor website were evaluated in the study. The criteria used in scoring which was made in TripAdvisor website were used exactly in the study. To determine the weight of these criteria, the weight was calculated in Super Decision program by taking evaluations of lecturers working at Beyşehir Tourism Faculty according to Saaty 1-9 scale. Thus, expert opinion was integrated with customer reviews in the study. Alternative four provincial orderings were obtained by combining weight of the criteria and TripAdvisor website customer score values in AHP technique. It is seen that provinces ordering hasn't changed even when integrated with the judgments of experts in 
terms of customer rewievs before study. In this context, it can be said that the criticism about the reliability of customer rewievs is not valid at least within this study.

This study matters in terms of the use of an approach which integrates eWOM applications in multi-criteria decision-making techniques and expert rewievs together. Besides, it will be able to set an example for other works about common rewiev to be determined by geometric mean when there are multiple decision makers in AHP method and how it is to be placed in comparison matrix. Another importance of this study is that restaurant management will be able to get a feedback about the current state of the business by taking advantage of this and similar studies.

\section{References}

[1] Asma,M., Bahurmoz, A.(2006). "The Analytic Hierarchy Process: a Methodology for Win-Win Management", JKAU: Econ\&Adm. Vol.20 No.1,3-16.

[2] Arrayo, M. M and Pandey, T. (2010). "Identification Of Critical Ewom Dimensions For Music Albums", Proceedings of the 2010 IEEE ICMIT, 1230-1235.

[3] Bilim,Y., Başoda, A. and Özer, Ö.,(2013). "Elektronik Tüketici yorumlarının Nitel Çözümlemesi ve Pazarlama Bilgi Aracı Olarak Kullanımı: Tatil Otellerine Yönelik Bir Uygulama",14.Ulusal Turizm Kongresi, 387-407.

[4] Boulding, W., Kaire A., Stealin, R. and Zeitham, V.A. (1993), A Dynamic Process Model Of Service Quality: From Expactions To Behavioral Intentions, Journal Of Behavioral Science, Vol.9.1., p.8-17

[5] Civelek, M and Dalgın, T., (2013). "Turizm Pazarlamasında Sosyal Medya, Turizm İşletmeleri Üzerine Bir Araştırma: Muğla Örneği", 14.Ulusal Turizm Kongresi, 266-282.

[6] Celik, N. (2007). "Bartın Illi'nde Faaliyet Gösteren Turizm İşletme Belgeli Üç Yııdızlı Otel İşletmelerinin Hizmet Kalitesi Áçısından Analitik Hiyerarși Süreci Yöntemi ile Karşılaştırıması", Yayınlanmamış Yüksek Lisans Tezi, Zonguldak Karaelmas UUniversitesi SBE.

[7] Forman, E. H., Peniwati, K. (1998). "Aggregating Individual Judgments and Priorities With The Analytic Hierarchy Process", European Journal of Operational Research, 108, 15-169.

[8] Forman, E. H., Selly, M. A.(2001) Decision By Objectives (How To Convince Others That You Are Right), World Scientific Pub. Co., Petersburg, USA, 2001.

[9] Giriner, N., Çevdar, Z.(2007). "En uygun Fiyatlandırma Stratejsinin Grup Karar Vermeli Analitik Hiyerarşi Süreci ile Değerlendirilmesi: Türkiye Otomotiv Sektörü İ̧̧in bir Uygulama", 22.Yıl Ağustos 2007 İktisat İşletme ve Finans Inceleme-Araştırma Dergisi, 101-127.

[10] Hafeez, K., Zhang, Y. B.and Malak, N. (2002). "Derermining Key Capabilities of A Firm Using Analytic Hierarchy Process", Int.J.Production Economics, 76.,39-51.

[11] Jeong, E. \& Jang, S. (2011). Restaurant experiences triggering positive electronic wordof-mouth (eWOM) motivations. International Journal of Hospitality Management, 30, 356-366.

[12] Ömürbek, N., and Tunca, M. Z. (2013). "Analitik Hiyerarşi Süreci ve.Analitik Ağ Süreci Yöntemlerinde Grup kararı Verilmesi Aşamasına Illişkin Bir Örnek Uygulama”, Súleyman Demirel Üniversitesi I.I.I.B.F.Dergisi, C.18, S.3:47-70.

[13] Önder, G.,and Önder, E.(2014). Çok Kriterli Karar Verme. içinde Yıldırım, B. F. ve Önder, E, Çok Kriterli Karar Verme Yöntemleri,(ss.21-64) Bursa, Dora Yayınları.

[14] Özaslan, Yasin; Uygur, Selma Meydan.( 2014 ). Negatif Ağızdan Ağıza İletişim (Wom) Ve Elektronik Ağızdan Ağıza illetişim (E-Wom): Yiyecek-ìcecek İşletmelerine Yönelik Bir Araştırma. Ataturk University Journal of Economics \& Administrative Sciences, 28.3.

[15] Özen,Ü. and Orçanlı, K. (2013). "Çok Kriterli Karar Verme Yöntemlerinden AHP ve Topsıs'in E-Kitap Okuyucu Seçiminde Uygulanması" http://sosyaldergi.usak.edu.tr/Makaleler/1128425974_MAKALE_14.pdf, (Erişim Tarihi: 02/02/2015)

[16] Pollach, I. (2006). "Electronic Word Of Mouth: A Genre Analysis Of Product Reviews On Consumer Opinion Web Sites", Proceedings of the 39th Hawaii International Conference on System Sciences, 1-10.

[17] Saaty, T. L. (1986). "Axiomatic Foundation of the Analytic Hierarchy Process", Management Science, Cilt 32, Sayı 7 , 841-855.

[18] Saaty, T. L. (2008). "Decision Making with the Analytic Hierarchy Process", International Journal of Services Sciences, Cilt 1, Sayı 1, 83-98.

[19] Saaty, T. L. and Özdemir, M. S.(2003). "Why the Magic Number Seven Plus or Minus Two", Mathematical and Computer Modelling, Cilt 38, 233-244. 
[20] Sarış̧ı, M. and Hatipoğlu, A. (2009). Türkiye'de Yiyecek Iç̧ecek Sektörünün Gelişimi. Editörler, Çavuş vd., Türk Turizm Tarihi Yapısal ve Sektörel Gelişim, Detay Yayıncllik, Ankara.

[21] Sarışıı, Mehmet; Özbay, Gülçin. (2012). Elektronik ağızdan ağiza iletişim ve turizm endüstrisindeki uygulamalara ilişkin bir yazın incelemesi. Uluslararası Yönetim Iktisat ve İşletme Dergisi, 8.16: 1-22.

[22] Timor,M. (2011). Analitik Hiyerarşi Prosesi, İstanbul, Türkmen Kitabevi.

[23] TUROFED (2014), "Turizmin Genel Değerlendirilmesi".

[24] Wordl Tourism Organization (2014), Online Guest Reviews and Hotel Classification Systms- An Integrated Approach, UNWTO, Madrid.

[25] Zhang, Z., Ye, Q., Law, R. and Li, Y. (2010). The Impact of E-Word-of-Mouth on the Online Popularity of Restaurants: A Comparison of Consumer Rewievs and Editor Rewievs. International Journal of Hospitality Management, 29: 694700 . 